\title{
The Rush To Outsource: The Interplay Of Location And Dislocation
}

\author{
David P. Boyd (E-mail: d.boyd@neu.edu), Northeastern University
}

\begin{abstract}
In their quest for economic efficiency, American firms are increasingly outsourcing their processes as well as their products. Companies may outsource operations themselves or use the services of special outsource firms such as contract manufacturers and external service providers (ESPs). The present study focuses on evolving dynamics within these intermediaries, particularly their accelerated move to offshore operations. This paper examines the causes and effects of this trend. The first casualties register in the American workforce. Though U.S. firms and consumers enjoy some near-term benefit from this job transfer, long-term implications are ominous. By broadening their geographic locus and hiring local professionals, ESPs unwittingly expedite the emergence of an indigenous labor pool to replace them. Already domestic providers are encountering local ventures that offer value-added technology in "upstream" areas like architecture, development and integration. If such firms continue to gain recognition in high-end activity, they may credibly lay claim to the commodity work of product assembly and transaction processes. American firms are targeting these same areas, especially the nascent realm of business process outsourcing (BPO). As U.S. outsourcers rush relentlessly "downstream" and transplant their backend support services to overseas locations, they may be outsourcing their own future. The paper will give three case study examples at each end of this labor food chain. As domestic examples we include a domestic contract manufacturer and a BPO provider. Both firms have established an overseas presence. Lastly, we examine an overseas competitor leveraging its upstream success in high-value IT services to secure a beachhead in BPO.
\end{abstract}

\section{Introduction}

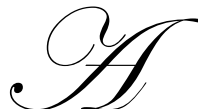

merican jobs are moving overseas at an accelerated clip. Having started two decades ago with low technology products, this emigration has progressively encompassed an ever-sophisticated spectrum of hardware. Now outsourced jobs also encroach upon high-level IT service areas as evidenced by a recent IBM conference call that was inadvertently publicized. After acknowledging its tardiness in effecting such transfers, Big Blue committed to outsource many high-level jobs, including engineering, software development, and chip design. Moreover, in pursuit of a "Best Shore" strategy, it would accelerate efforts to export transaction-based processes, including accounting, software support and call centers. High-speed digital communication allows ready access to technology expertise in other countries, thereby facilitating this trend toward business process outsourcing (BPO).

IBM's actions speak to an explosive pattern. Forrester Research estimates that in the next dozen years, 3.3 million jobs will be sent overseas, especially to India, and the bulk will be tied to the information technology industry. Gartner Research considers the shift "a megatrend in the IT services industry" (Greenhouse, 2003, p. 2). More than one quarter of the 500 largest U. S. firms are already immersed in outsourced operations (Schroeder, 2003). Representative Donald Manzullo, Chair of the House Small Business Committee, expresses alarm over the scope and scale of this transition: "What do you tell the Ph.D. or professional engineer or architect or accountant or computer scientist to do next? Where do you tell them to go?" While sensitive to market backlash, firms nonetheless perceive the move to offshore outsourcing as inexorable. Their pace is quick even if their plans are quiet. A recent Forrester Research report pegs America's lost wages at $\$ 136$ billion over the next 12 years (Frauenheim, 2002). 
This relentless rush to outsource operates at two levels. Firms may seek to build a global company of their own accord and simply move production or processes overseas. Alternatively, companies may outsource their products and processes to domestic providers who in turn utilize their overseas facilities. This second approach is increasingly popular and is the focus of this paper. Both routes lead beyond our shores.

\section{Product Outsourcing}

Product outsourcing has been a fact of life since the early 1980s as manufacturing companies moved their operations offshore. The migration to foreign locales began with low-end manufacturing such as toys and textiles. Now it has progressed to high-end manufacturing. Especially in the case of complex technology, OEMs can contract with domestic providers with offshore operations. The so-called "contract manufacturers" offer a complete range of electronic manufacturing services (EMS) from initial design through final assembly. Five of these EMS firms are recognized as top-tier: Celestica, Flextronics International, Jabil Circuit, Sanmina-SCI, and Solectron. The case of Jabil is especially instructive because of its solid execution in a down economy. It enjoys the best financial condition of any major EMS firm and continues to grow the fastest.

Jabil's solid operational metrics and strong balance sheet emanate, in part, from a distinctive business model predicated on continuous flow rather than batch grouping. Jabil forms employee "work cells" focused on a single customer. This structural format aligns the interests of employees and customers, propelling work cells toward a sense of product ownership. At the head of each team is a dedicated Business Unit Manager (BUM). This BUM is responsible for overseeing all aspects of customer interface, assuming the risks and rewards for the customer manufacturing relationship. This worldwide project manager also ensures that the values of the team resonate with Jabil's own core culture, allowing the work cell to be "a factory within a factory" (Lewis, 2002). Because it blends sales and production roles, the team works closely with vendors. This customer-centric approach breeds client loyalty and ensures consistent wins. By deliberately serving the smallest customer base in the EMS industry, Jabil can be attentive and responsive to its 50 core clients. This decentralized model also empowers employees at the business unit level, engendering commitment to the company and concern for the customer.

The firm's horizontal business strategy is another unique feature. Unlike its vertically integrated EMS peers, Jabil can competitively access the full gamut of external suppliers. In a desire to scale vertically and source internally, other contract manufacturers became encumbered with assets that precipitated massive restructuring charges. Rather than owning fabrication facilities, Jabil purchases components from its supply base, avoiding the high operating leverage and earnings volatility stemming from vertical services. As a result, the company can stay focused on internal growth.

In addition to a disciplined focus on core competencies, Jabil has a diversified market base. While increasing its automotive, consumer, instrumentation, medical and military mix, it has curtailed exposure to networking and telecom. To combat pricing pressure from OEM customers, Jabil has shifted manufacturing capacity to lower-cost geographies, including Mexico, Hungary and China. As a result management indicated that low-cost location is responsible for seventy percent of total capacity whereas as recently as 1997 high-cost locations were responsible for 70 percent of total capacity. Because worker skills continue to increase in low-cost regions, more and more production will transfer overseas. To accommodate demand shifts in manufacturing across a global theater, Jabil will depend on its flexible supply-chain solution for rapid configuration. Having been less acquisitive than its peers, Jabil can extend core values and like systems across its field of operations. The company prefers to start up or "greenfield" its own plants, allowing recruitment of culturally consonant individuals.

\section{Business Process Outsourcing}

BPO is the fastest growing market in the IT services sector. Having already outsourced to Hewlett Packard a $\$ 3$ billion ten-year deal for infrastructure management, Procter and Gamble is poised to award vendors more than $\$ 3$ billion in BPO services. As with product outsourcing, BPO permits companies to free up mindshare and focus on core competencies. Unlike the typically segmented approach of IT outsourcing, however, BPO's inherent focus is 
on process entirety. Clients can readily discern the special business drivers that emanate from a properly chosen provider (Halvey and Melby, 2000). Competent and committed outsourcers can provide the following benefits:

- Improve operational efficiencies and contain infrastructure by shedding resource-intensive, administrative functions and simultaneously shortening time-to-market

- $\quad$ Reduce transaction costs without adding overhead or large, upfront capital investments that rapidly depreciate

- $\quad$ Eliminate the need to recruit, retain and retrain skilled IT staff

- $\quad$ Gain access to advanced technology delivered by experts rather than relying on disparate legacy systems that lack flexibility and functionality

- $\quad$ Utilize a resource base that automatically scales to accommodate end demand

- $\quad$ Leverage channels for data mining and trend analysis, thereby securing input for future decisions

In sum, BPO advances a cultural mindset that values collaboration over control (Keen, 2002).

Continual drops in the cost of technology have caused margin erosion in the ITO offerings of computer service companies. However, the BPO cycle is still early stage so it has not yet encountered pricing pressure. Contracts are long-term, providing recurrent revenue from commercial and government clientele. A BPO provider offers secure, stable processing of time-critical, transaction-intensive data. Moreover, to the outsourcers themselves, the operating leverage inherent in the BPO model affords an attractive return profile. Since it is typically transaction-based, BPO revenue carries higher margins than ITO and systems integration. In a Dataquest Alert, Gartner predicted that supplier BPO revenues would grow to $\$ 173$ billion by 2007 (Scholl et al., 2003). Services that lend themselves to BPO include customer relationship management, accounting-finance, human resources, logistics, security, and supply chain management.

Affiliated Computer Services (ACS) is a global Fortune 1000 company that serves over 10,000 clients and posted FY02 revenue that exceeded $\$ 3$ billion. Though ACS offers systems integration services that include design, development and maintenance along with technology outsourcing of all IS requirements, the company is shifting its business mix to high-margin BPO. The company has been resilient in a down economy because more than 65 percent of revenues emanate from the BPO market. Its home page proclaims: "Your non-core processes are our core business." Among its clients are General Electric, American Express, MetLife, UPS, and Prudential Insurance as well as the State of New York and the State of New Jersey. ACS serves eight out of the top 10 healthcare providers in the world, processing 500 million claims per year.

Like its EMS counterparts, ACS utilizes offshore operations. For example, when a claim from MetLife arrives at ACS' Kentucky headquarters, ACS scans the document whereupon an image "is almost simultaneously beamed offshore" (p. 2) for data capture through the firm's proprietary satellite network. Scanning and image routing are thus a matter of seconds. When these images arrive at ACS centers in Ghana, Mexico, the Caribbean, Guatemala or China, operators key in the digitized images that are then automatically verified for comparable entry (Harney, 2003). In terms of plans to outsource offshore, global financial institutions like MetLife appear to be on the "cusp of a revolution" (p. 1). A Deloitte study of 27 firms, including 11 of the top 20, found that 75 percent would be outsourcing in the next 24 months and their plans included BPO (Rosenthal, 2003).

The finding is reflective of Jack Welch's assertion that 70 percent of GE Capital's work would be outsourced, 70 percent of that offload would go offshore, and 70 percent of the offshore business would be relegated to India (Business World, 2000). According to a 2002 Nasscom-McKinsey study, India has become the world's back office where IT services have burgeoned 70 percent in two years. BPO's spread has been especially speedy in HR, finance/accounting, call centers, medical transcription and billing functions (Goolsby and Parrino, 2003). Electronic Data Systems and Accenture are expanding IT operations in both India and China. By combining offshore with onshore services, EDS can provide clients with 24/7 "follow the sun" support. At the end of 2004, EDS predicts that it will have 20,000 offshore employees. With its competitors moving jobs offshore, IBM plans to do likewise. Jobs commanding over $\$ 60,000$ a year at Big Blue would fetch little more than $\$ 6000$ a year in India (Loftus and Fuscaldo, 2003). The Gartner Group estimates that wage rates in countries like India and the 
Philippines reflect an 80 percent discount to the remuneration scale in the United States though additional costs are associated with managing an offshore labor pool (Harney, 2003).

Fueled by the lure of high margins, formidable BPO competitors are challenging ACS. EDS, IBM and Accenture collectively boast $\$ 40$ billion in services revenue. Moreover, while ACS has worldwide production facilities in the Americas, Europe, Africa, Australia and the Middle East, it lacks the global presence of its larger brethren. Yet the organic growth rate of ACS solidly surpasses that of its rivals, and the company has garnered a dominant position in the emergent BPO market. As evidence of its ascendancy, ACS secured a six-year HR BPO contract with Motorola. This win augments the capability and credibility of ACS, placing it at the forefront of incipient efforts to outsource the entire HR function. The market for HR BPO is likely to be enormous. It is instructive that ACS could make a case with Motorola whose HR function was considered traditional and conservative. One of ACS's rivals depicts a "Relationship Compass" that describes different forms of outsourcing arrangements; these relationships range from providing niche services to transforming enterprise outcomes (Accenture, 2002). In the case of HR BPO, it is conceivable that the provider role might over time evolve from simple transaction processor to substantive transformation partner. In like fashion the authors of another white paper suggest that "maintenance" sets the stage for a subsequent broader relationship (Goldstone Technologies, 1999). A manufacturer in Texas noted an inherent self-fulfilling prophecy. If a company is satisfied with functions that it has outsourced, "the more functions it considers outsourcing" (Swarts, 2003, p. 2).

\section{The Road Ahead}

\subsection{New Companies}

As U.S. outsourcers increasingly invade Indian turf, they encounter indigenous firms that have proven success in upstream areas. Indian ESPs such as Infosys, Wipro and Bombay-based Tata Consultancy Services have shown sophistication in high-level IT consulting, software and integration services that enable e-business. In domain expertise they rival global service providers such as Accenture, EDS and IBM. The National Association of Software and Service Companies estimates that the top Indian firms will gross $\$ 12$ billion in export revenues this year. Growth in the software and services sector surpasses 30 percent per year and constitutes 18 percent of the country's aggregate exports (Rai, 2003). The premier Indian companies already boast such American clients as General Electric, American Express and Nike. Seventy percent of India's software services exports are destined for the United States (Kripalani, Einhorn, and Magnusson, 2003). More than 300 of the Fortune 500 firms already have business dealings with Indian IT services companies (Frauenheim, 2002).

Having mastered application development and tactical IT projects, these Indian firms are poised to pounce in areas such as payroll and transaction processing. Wipro offers a case in point. Its recent purchase of a small entrepreneurial Boston firm extended its depth and presence in systems integration, architecture development and IT consulting. However, in a quest for vertical enhancement, it also acquired American Management Systems' global energy practice. Finally, Wipro is the first large Indian ESP to foray into BPO through its acquisition of Spectramind. While initial BPO revenues are modest, they reflect Wipro's opportunistic mentality, and the company is starting to make headway in finance, accounting, and customer support. Only a decade ago Wipro was a prosaic conglomerate selling cooking oil and personal computers into a domestic market. Today it is interpreting radiology images for a pre-eminent American research hospital, essentially "providing the hospital's second and third shifts" (Hammonds, 2003, p. 94). Moreover, through the auspices of a java-based protocol, Wipro manages the applications that power the regulatory-compliance processes of the New York Stock Exchange. Application development thus seems a logical precursor to management of the data developed through the application. As evidence of its momentum, Wipro added 38 clients in the first quarter and increased its employee ranks by more than 2200 .

In turning to local firms like Wipro, American clients do not forego quality in return for lower price. According to Forrester Research, these lower labor costs are often coupled with process controls that are more stringent than those in the United States (McDougall, 2002). U.S. providers currently enjoy competitive advantage due to their established base of large clients. Yet Indian workers tend to be well educated, fluent in English and 
increasingly sensitive to the nuances of American corporate culture (Rai, 2003). Simply put, the United States is not the exclusive province of top talent. Not surprisingly, American outsourcers recognize the virtues of the Indian workforce, and even troubled EDS is committing \$100 million to launch a BPO center in India. Forrester Research estimates that over the course of the coming decade, large U.S. companies may transfer as many as 3.3 million positions to India (Black and Kripalani, 2003). A job emigration of this proportion will open opportunities for locals at American firms. No longer will indigenous providers like Wipro be the prime employment option. Yet managers at companies like IBM must wonder whether "we're training our own replacements" (Hammonds, 2003, p. 98). A plausible scenario would have loyalty to country surpass loyalty to company. A Wipro employee opined: "All of us were brought up with the thought that India was once great. We had such a rich heritage. Under the British, we lost a lot of that. Now we're rebuilding" (Hammonds, 2003, p. 97). This reclamation of heritage may extend to Indian professionals employed by American overseas outsourcers. By broadening their geographic locus, American firms may ultimately forfeit their hold on world markets.

\subsection{New Countries}

India is indisputably the world's back office, but confluent factors are facilitating China's emergent role. The country contains more than a billion people, many willing to work for comparatively low wages. In the words of one observer, this "low cost labor provides a pure labor arbitrage opportunity for many advanced economies" Furniss, 2003, p. 2). American BPO firms might pay $\$ 500$ monthly to an engineer in Shanghai, $\$ 700$ to one in India, and $\$ 4000$ in the United States (Einhorn and Kripalani, 2003). Since contracts are not awarded on the basis of cost alone, the Chinese leadership is developing an educational infrastructure to advance the skills of the populace. Taking a cue from India's emphasis on technical education, China is investing in a host of educational ventures, from exclusive learning academies to more accessible televised instruction. Its technical schools now produce 50,000 graduates a year (DiCarlo, 2003). As China assimilates into the World Trade Organization, it is likely to curtail restrictive legislation, liberalize trade policies, and respect intellectual property. If China's climate continues to be receptive, it will spur Western multinationals to consider Chinese transaction centers.

Within China itself, a burgeoning middle class is gearing for avid consumption. J. P. Morgan Chase reports that 2002 car sales in China rose 54 percent while housing sales increased nearly 40 percent (Furniss, 2003). Moreover, China's geographic situation is fortuitous. Leveraging physical proximity and linguistic ties, China might surface as a major trading hub for Japanese and Korean multinationals. Gartner Inc. predicts that by 2007, China will achieve parity with India in terms of revenue draw from IT services (Einhorn and Kripalani, 2003). India is hardly oblivious to the perfect storm that might be brewing and is determined to parlay its own IT infrastructure to secure Chinese clients.

\subsection{New Constraints}

A BPO backlash is galvanizing legislative momentum. Four bills have been drafted to reform the visa system. By closing certain immigration loopholes, Congress could make it difficult for high tech workers from other countries to be trained in the United States. Many fear that such freshly honed workers have been leaving the United States to help home country firms accommodate outsourced contracts. Ironically, just a few years ago the H1B visa program was expanded to calm fears about a growing shortage of high-tech workers in the United States. The L1 visa is even more controversial than the H1B. While the H1B pertains to a single filer, the L1 can encompass a bevy of employees in one fell swoop. Moreover, contrary to provisions exacted for H1B issuance, L1 visas need not pay "prevailing wages" nor need employers demonstrate prior effort to recruit U.S. employees for the positions in question. Further, critics remonstrate that extensions of existing visas should be counted against the total cap (Ante and Magnusson, 2003). In the end some kind of reform seems likely, both in regard to enforcing existing regulations and enacting new ones. The saga will also play out at the local level where four states are now considering a ban on government BPO contracts to low-wage developing countries. Even if such draconian measures do not prevail, they foster a climate where outsourcing seems unprofessional and unpatriotic.

Restrictions on outsourcing might also surface through tax code revisions. Some IT workers have proposed incentives for companies whose entire production process occurs within the United States. Less simplistic measures 
might include tax credits for initiatives like flexible capital spending. By allowing a greater number of products to be made in a smaller number of facilities, manufacturers could reduce their fixed cost structures. Such credits would serve as a financial catalyst for revamped production, thereby increasing capacity and weakening the rationale for outsourced operations.

\section{Conclusion}

Is outsourcing more bad than good? If so, can anything be done to rectify the situation? Value judgments might best be tendered from a stakeholder perspective. For the individual firm doing the outsourcing, near-term effects are arguably salutary. Through BPO alone, this country has saved more than seven billion dollars in the last four years (Times of India, 2003). In countries like India, stringent standards exist for both products and processes. American outsourcers can thus keep a lid on prices with no diminution of product performance. Satisfied American consumers will then increase purchases in the marketplace. Given this optimal combination of capability and cost, the Giga information Group predicts that clients will increasingly pressure outsourcers to utilize foreign labor components as part of every deal (Frauenheim, 2003). An outsourcing firm thereby ensures cost containment as well as revenue enhancement. The immediate physical victims are, of course, severed employees; the psychic effects are even larger since the residual pool fears displacement. Such perceived vulnerability could spur unionization, a move aggravated by the downward wage pressure that outsourcing trends exert on the domestic pool. Companies reason that job transfer permits home-based survivors to focus on higher-value work. This rationale is largely a rhetorical rationalization (Morello, 2003). Some pundits predict that globalization will decimate the U.S. educated class even as it did the blue-collar workforce in preceding decades (Mandell, 2003). The global knowledge industry shines ever more brightly on developing nations.

These offshore programmers have been accorded the sobriquet of "code warriors" because they tested so many millions of lines of application software. Now, however, they may be pioneers in a paradigm shift in the delivery of IT services. Moreover, by creating and training a foreign workforce that has no natural allegiance to the parent company, American firms may be handing knowledge and advantage to their own competitors. We might be grooming the very entrepreneurs who will be competing with us.

Rising unemployment presages less consumption. By outsourcing and downsizing, U.S. firms will eviscerate the purchasing power of many domestic consumers. Such firms must then depend on consumers in the countries where they are sourcing. However, such support may prove tepid and temporal. American BPO providers are already reducing their rate structures in an effort to render them commensurate with Indian competitors. Is such "soft currency" truly attractive? Thus, even the near-term perceived benefits of outsourcing may undo the very parties now benefiting from it. There is no shareholder enhancement when foreign firms garner the business.

By allowing rampant outsourcing of their products and services, Americans may be outsourcing their own future. Yet legislative mechanisms are no panacea for our problems. Rather than "protecting" production by keeping it inside the country and proscribing other professionals from infringing on our turf, we should strive to make others want our goods and services. We must pursue innovation and offer our discoveries in real time at reasonable prices. If we seek to undermine importation of quality items through price barriers, we refute "a law of economic physics" (Kenton, 2003, p. 2). Technology production and processing can move overseas, but technology research and design must flourish within our own borders. As Kenton observes, there is a fundamental difference between outsourcing efficiency and outsourcing innovation. A Washington official recently noted that the hallmark of our technological prowess was the creative capacity to invent and not just the production process itself. If there is any case for governmental intervention here, it involves the workers caught in transition and their need for skill enhancement. By supporting the professional development of the workforce and creating incentives for corporate $\mathrm{R} \& \mathrm{D}$, the public sector can help American firms invest in innovation. Ironically, as long as foreign nationals enroll in our universities and enlist in our labor pool, they validate the power of our technological prowess. Thus, American professionals must continuously craft ideas that other countries will embrace. 


\section{References}

1. Accenture. 2002. Business process outsourcing big bang. Cambridge, MA: Accenture Institute for Strategic Change.

2. Ante, Spencer E. and Magnusson, Paul. 2003. "Too many visas for techies?", Business Week, August 18.

3. Black, Jane and Kripalani, Manjeet. 2003. "India: Hungry for info tech", BusinessWeek Online, March 4.

4. DiCarlo, Lisa. 2003. "Best countries for outsourcing". Forbes, August 27.

5. $\quad$ Einhorn, Bruce and Kripalani, Manjeet. 2003. "Move over, India”. Business Week, August 11.

6. $\quad$ Frauenheim, Ed. 2002. "U.S. firms move IT overseas". CNET News.com, December 11.

$7 . \quad$ 2003. "IT plans sending more services overseas". CNET News.com, March 12.

8. $\quad$ Furniss, Todd. 2003. "China: the next big wave in offshore outsourcing", BPO Outsourcing Journal, June.

9. Goldstone Technologies. 2000. Software product support and maintenance outsourcing. Vienna, VA: Goldstone Technologies Limited.

10. Goolsby, Kathleen and Parrino, Steve. 2003. "The expanding territory of offshore outsourcing", OutsourcingOffshore.com, January.

11. Greenhouse, Steven. 2003. "IBM explores shift of white-collar jobs overseas". New York Times, July 21.

12. Halvey, John K. and Melby, Barbara Murphy. 2000. Business process outsourcing: Process, strategies, and contracts. New York: John Wiley.

13. Hammonds, Keith H. 2003. "The new face of global competition", FastCompany.com, February.

14. Harney, John. 2003. "Staking a claim to excellence with an offshore component", OutsourcingOffshore.com, March.

15. Keen, Peter G. W. 2002. Business process outsourcing. El Segundo, CA: Computer Sciences Corporation.

16. Kenton, Christopher. 2003. "Grasping, greedy, unpatriotic? Not me.”, BusinessWeek Online, April 25.

17. . 2003. "What I told Congress", BusinessWeek Online, June 30.

18. Kripalani, Manjeet, Einhorn, Bruce, and Magnusson, Paul. 2003. "A new battle over offshore outsourcing", Business Week Online, June 6.

19. Lewis, Chris. 2002. "Chief financial officer of Jabil Circuit discusses strategic direction", Wall Street Transcript, June 12.

20. Loftus, Peter and Fuscaldo, Donna. 2003. "Offshore trend continues, with or without IBM", Dow Jones Newswires, July 22.

21. Mandel, Michael J. 2003. “Outsourcing jobs: Is it bad?”, Business Week, August 25.

22. McDougall, Paul. 2002. "Budget-bled executives are looking east". InformationWeek.com, December 16.

23. Morello, Diane. 2003. "Offshore outsourcing bodes poorly for some careers". Gartner.com Weblog Update, July 25.

24. Rai, Saritha. 2003. "Indian companies are adding western flavor", New York Times, August 18.

25. Rosenthal, Beth Ellyn. 2003. "Deloitte study discovers 75 percent of global financial institutions plan to outsource offshore", BPO Outsourcing Journal, June.

26. Schroeder, Michael. 2003. "Unions and states aspire to block job outsourcing", Career Journal.com.

27. Scholl, Rebecca S., Tornbohm, Cathy, Datar, Ravi, Narisawa, Rika, Hale, Kathryn, and De Souza, Robert. 2003. BPO market to grow to $\$ 173$ billion in 2007. Stamford, CT: Gartner Dataquest Alert.

28. Swarts, Katherine. 2003. "Manufacturing the future", OutsourcingManufacturing.com, January.

29. Times of India. 2003. "Government sets up panel to tackle BPO backlash". August 9. 
Notes 